\title{
Effects of Bos taurus autosome 9-located quantitative trait loci haplotypes on the disease phenotypes of dairy cows with experimentally induced Escherichia coli mastitis
}

\author{
M. Khatun, ${ }^{\dagger}$ P. Sørensen, $†$ H. B. H. Jørgensen, $†$ G. Sahana, † L. P. Sørensen, † M. S. Lund, † K. L. Ingvartsen, ${ }^{*}$ \\ A. J. Buitenhuis, $†$ J. Vilkki,ł M. Bjerring, ${ }^{*}$ J. R. Thomasen, $\S$ and C. M. Røntved $\#^{1}$ \\ *Department of Animal Science, and \\ †Center for Quantitative Genetics, Department of Molecular Biology and Genetics, Faculty of Science and Technology, Aarhus University, \\ PO Box 50, DK-8300 Tjele, Denmark \\ ¥Biotechnology and Food Research, MTT Agrifood Research Finland, 31600 Jokioinen, Finland \\ $\S$ VikingGenetics, Elbeltoftvej 16, DK-8900 Randers, Denmark \\ \#CMR On-Site RD, Skjernvej 4A, DK-9220 Aalborg Øst, Denmark
}

\section{ABSTRACT}

Several quantitative trait loci (QTL) affecting mastitis incidence and mastitis-related traits such as somatic cell score exist in dairy cows. Previously, QTL haplotypes associated with susceptibility to Escherichia coli mastitis in Nordic Holstein-Friesian (HF) cows were identified on Bos taurus autosome 9. In the present study, we induced experimental E. coli mastitis in Danish HF cows to investigate the effect of $2 \mathrm{E}$. coli mastitis-associated QTL haplotypes on the cows' disease phenotypes and recovery in early lactation. Thirty-two cows were divided in 2 groups bearing haplotypes with either low (HL) or high (HH) susceptibility to E. coli. In addition, biopsies (liver and udder) were collected from half of the cows $(n=16)$, resulting in a $2 \times 2$ factorial design, with haplotype being one factor (HL vs. HH) and biopsy being the other factor (biopsies vs. no biopsies). Each cow was inoculated with a low E. coli dose (20 to $40 \mathrm{cfu}$ ) in one front quarter at time $0 \mathrm{~h}$. Liver biopsies were collected at $-144,12,24$, and $192 \mathrm{~h}$; udder biopsies were collected at $24 \mathrm{~h}$ and 192 $\mathrm{h}$ post- $E$. coli inoculation. The clinical parameters: feed intake, milk yield, body temperature, heart rate, respiration rate, rumen motility; and the paraclinical parameters: bacterial counts, somatic cell count (SCC), and milk amyloid A levels in milk; and white blood cell count, polymorphonuclear neutrophilic leukocyte (PMNL) count, and serum amyloid A levels in blood were recorded at different time points post- $E$. coli inoculation. Escherichia coli inoculation changed the clinical and paraclinical parameters in all cows except one that was not infected. Clinically, the $\mathrm{HH}$ group tended to have higher body temperature and heart rate

Received March 12, 2012.

Accepted November 28, 2012.

${ }^{1}$ Corresponding author: cmr@cmr-on-site.dk than the HL group did. Paraclinically, the HL group had faster PMNL recruitment and SCC recovery than the HH group did. However, we also found interactions between the effects of haplotype and biopsy for body temperature, heart rate, and PMNL. In conclusion, when challenged with $E$. coli mastitis, HF cows with the specific Bos taurus autosome 9-located QTL haplotypes were associated with differences in leukocyte kinetics, with low-susceptibility cows having faster blood PMNL recruitment and SCC recovery and a tendency for a milder clinical response than the high-susceptibility cows did.

Key words: Escherichia coli, mastitis, quantitative trait locus haplotype, phenotype

\section{INTRODUCTION}

Mastitis, an inflammatory condition of the mammary gland, is the most prevalent disease in periparturient dairy cows (Burvenich et al., 2007; Fox, 2009). Bovine mastitis causes substantial economic losses to the dairy industry because of decreased milk yield, treatment cost, prevention cost, and culling of the affected animals (Petrovski et al., 2006; Bar et al., 2008; Hertl et al., 2011). Moreover, mastitis is considered a painful condition of animal welfare concern (Rasmussen et al., 2011; Fogsgaard et al., 2012). Hence, lowering the risk and incidence, and improving recovery from mastitis through improved breeding is desirable to the dairy industry.

The gram-negative bacterium Escherichia coli, belonging to the Enterobacteriaceae family, is one of the most common causes of acute clinical mastitis in dairy cows in early lactation (Bradley et al., 2007; Ericsson Unnerstad et al., 2009; Hertl et al., 2011). Escherichia coli mastitis is associated with well-characterized clinical signs and subclinical and clinical changes in milk and blood components. The clinical and paraclinical 
changes, termed "evident phenotype" (Detilleux, 2009), are considered the disease phenotypes during mastitis. The common clinical disease phenotypes during E. coli mastitis are high fever and anorexia with lowered milk production (Burvenich et al., 2003; Bannerman et al., 2004; Kornalijnslijper et al., 2004). The disease phenotypes expressed in milk are a brief excretion of high numbers of $E$. coli, followed by a dramatic increase in SCC and inflammatory mediators and altered milk appearance (Kornalijnslijper et al., 2004; Vangroenweghe et al., 2004; Vangroenweghe et al., 2005), depending on the severity of the infection (Bannerman et al., 2004; Suojala et al., 2008). Similarly, the important disease phenotypes expressed in blood are leukocyte mobilization with short-term leukopenia, followed by leukocytosis (Vels et al., 2009; Rasmussen et al., 2011) and secretion of large quantities of inflammatory mediators including cytokines (Bannerman et al., 2004) and acute-phase proteins (Jacobsen et al., 2005; Suojala et al., 2008). Among the commonly investigated acute-phase proteins are milk amyloid A (MAA) and serum amyloid A (SAA), which have been suggested to be associated with the degree of infection (Jacobsen et al., 2005; Suojala et al., 2008) and the related tissue trauma (inflammation) (Cray et al., 2009).

Host defense against mastitis is controlled by multiple genes (Pighetti and Elliott, 2011), and the outcome of clinical mastitis may be affected by several host factors, including QTL or QTL haplotype (Lund et al., 2008; Sodeland et al., 2011). In Nordic Holstein-Friesian (HF) cows, the SCS is affected by a QTL located on BTA9 that is partly associated with E. coli mastitis, with one haplotype being more susceptible and another being more resistant (Sørensen et al., 2008). Indeed, increasing numbers of studies are investigating the underlying molecular mechanism of $E$. coli mastitis from an immunological point of view (Buitenhuis et al., 2011). Furthermore, numerous studies investigating the effect of SNP in the bovine immunological genes on mastitis susceptibility are emerging (Leyva-Baca et al., 2008; He et al., 2011; Pighetti and Elliott, 2011). Although several QTL affecting mastitis incidence and mastitis-related traits such as SCS exist in dairy cows, only few studies have examined the effect of specific QTL or QTL haplotypes in an experimental setup. Recently, primary bovine mammary gland epithelial cells originating from cows with specific SCS-associated QTL on BTA18 were infected with E. coli and investigated for multiple gene expression using quantitative real-time PCR and microarray expression chip technology (Griesbeck-Zilch et al., 2009; Brand et al., 2011). However, so far no one has investigated the direct effect of the BTA9 QTL haplotypes on common clinical, milk, and blood disease phenotypes during experimental $E$. coli mastitis. Studying the effect of QTL haplotypes on clinical outcome and disease recovery may provide novel insights into the genetic basis of the pathophysiology of bovine $E$. coli mastitis.

The aim of the present study was to test the hypothesis that the BTA9 QTL haplotypes are partly associated with $E$. coli mastitis, with one cow haplotype being more susceptible and another being more resistant to $E$. coli mastitis. The effect of QTL haplotypes on the clinical and paraclinical disease phenotypes associated with E. coli mastitis was tested in an experimental in vivo model using a low bacterium dose. We also collected liver and udder biopsies from half of the cows for gene expression analyses. The results from these studies were presented in Buitenhuis et al. (2011) and Jørgensen et al. (2012). As this combined biopsy procedure may have caused additional stress and inflammation, the biopsy procedure was included as a statistical factor in our study. The main effect of the factor biopsy is presented elsewhere (M. Khatun, P. Sørensen, K. L. Ingvartsen, M. Bjerring, and C. M. Røntved, unpublished data), whereas the interaction effect between biopsy and QTL haplotype on the investigated parameters are presented here.

\section{MATERIALS AND METHODS}

\section{Selection of Animals}

The experiment was performed at Aarhus University, Department of Animal Science (Foulum, Denmark). All procedures involving animals were approved by the Danish Animal Experiments Inspectorate in accordance with the Danish Ministry of Justice Law no. 726 (September 9,1993) and acts 739 (December 6, 1988) and 687 (July 25, 2003) concerning animal experimentation and the care of experimental animals. Inspection was carried out by members of the Danish Animal Experiments Inspectorate committee during the acute stage of the disease.

The Danish HF breed was used in this study. Potential carriers (bull daughters) of the high-or lowmastitis-resistance QTL haplotype were identified in the Danish National Cattle Database (https://www. landbrugsinfo.dk/Kvaeg/RYK/Sider/Registrerings-

blok_web.pdf; http://www.glr-chr.dk/pls/glrchr/chrmenu $\$$.menu) by assessing the haplotype status of their sire and grandsire. Daughters were also matched with regard to age, expected calving date (1.5 to 2 mo before expected calving date), and health status record (i.e., free of Salmonella dublin, bovine viral diarrhea virus, group B Streptococcus, infectious bovine rhinotracheitis virus, and low antibody titers against Para tuberculosis in milk and serum). Forty-two pregnant heifers (20 in 
winter and 22 in summer) were purchased from the farmers and transferred to the Aarhus University dairy barn after confirmation of QTL haplotype as described below. The experiment ran for about $3 \mathrm{mo}$ in the spring and $3 \mathrm{mo}$ in the summer of 2007. Prior to experimentally induced E. coli mastitis, the general health and udder health status of all cows were evaluated based on rectal temperature, white blood cell (WBC) count, the glutaraldehyde test, the California Mastitis Test (CMT; score 1 to 5; Pyörälä, 2003; Jørgen Kruuse A/S, Marslev, Denmark), and bacteriological examinations of foremilk samples. Only cows with normal body temperature, WBC count, negative glutaraldehyde test, low CMT score (1 or 2), and which were free from major mastitis pathogens were used. Ten cows served as reserves until the post- $E$. coli inoculation $(\mathbf{P I}) \mathrm{d}$ or $\mathrm{h} 0$, picking the most healthy and least nervous cows when biopsying.

\section{QTL Haplotype Analysis}

In a previous study, a QTL affecting clinical mastitis and SCS was mapped on BTA-9 in Danish HF cattle (G. Sahana, Center for Quantitative Genetics, Department of Molecular biology and Genetics, Faculty of Science and Technology, Aarhus University, Foulum, Denmark, personal communication). The QTL explained $2.21 \%$ of the genetic variance for clinical mastitis in the $\mathrm{HF}$ discovery population.

Four grandsire families and 255 progeny-tested sons were genotyped with microsatellite markers and QTL analysis was performed using linkage analysis and combined linkage disequilibrium and linkage analysis (Lund et al., 2003; Sahana et al., 2008). The linkage analysis had the highest likelihood ratio test at $42.93 \mathrm{cM}$ on chromosome 9, with the QTL interval spanning $22 \mathrm{cM}$. The maximum likelihood ratio test statistics for both linkage disequilibrium and linkage analysis and linkage disequilibrium analysis alone were located at the same position of the chromosome. A 0.52-cM haplotype consisting of 6 microsatellite markers was identified, which explained the QTL variance within this QTL interval. The founder haplotypes (263; 8 grandsire haplotypes plus 255 dam haplotypes) were grouped into 55 clusters based on identity-by-descent probabilities. The allelic combinations and haplotype effects on clinical mastitis and SCS were estimated for the haplotype clusters with high frequencies. Within-family linkage analysis revealed that 1 grandsire (Lord Lily) was segregating a mastitis-resistance QTL. The 2 haplotypes carried by this grandsire (Lord Lily) were identified. A new group of 345 individuals (106 sires and 235 heifers) was genotyped for these 6 microsatellite markers. The haplotypes were constructed using PHASE software
(Stephens and Donnelly, 2003). The HF heifers carrying 1 of the 2 haplotypes (low susceptibility, HL or high susceptibility, $\mathbf{H H}$ ) of the segregating grandsire (Lord Lily) were identified and recruited for the E. coli challenge experiment. It was ensured that none of these heifers carried both haplotypes (HL and $\mathrm{HH}$ ).

\section{Experimental Design}

A $2 \times 2$ factorial block design was used to study the effect of QTL haplotype on clinical and paraclinical disease phenotypes in E. coli mastitis. However, as repeated combined liver biopsies and udder biopsies were collected from half of the cows $(n=16)$ for gene expression analysis, the effect of biopsy and the interaction effect of QTL haplotype with biopsy were also investigated. One group was cows with HL to $E$. coli mastitis and the other group was cows with $\mathrm{HH}$ to E. coli mastitis. For the interaction effect, cows were divided into 4 groups: the HL group with biopsy (HLB) or no biopsy (HLNB) and the HH group with biopsy (HHB) or no biopsy (HHNB). One week ( $-192 \mathrm{~h} \mathrm{PI}$ ) before E. coli inoculation, 24 of the 42 cows were randomly selected for liver biopsy. Thirty-two cows were inoculated with E. coli 4 to 6 wk after parturition; this was set as time point $0 \mathrm{~h}$. Sixteen of the 24 biopsied cows continued in the $E$. coli trial on the combined liver and udder biopsy procedure. For convenience, the trial was divided into 4 groups of 8 cows and biopsies were collected from 4 cows in each group. Because of additional disease and delayed milk let-down, 3 cows could not be studied for the entire experimental period and were discarded from the statistical analysis. Hence, 16 HL cows (HLB: $n$ $=8$; HLNB, $\mathrm{n}=8)$ and $13 \mathrm{HH}(\mathrm{HHB}, \mathrm{n}=8$; HHNB, $\mathrm{n}=5$ ) cows were analyzed for the haplotype effect on clinical and paraclinical disease phenotypes. The time points of the experimental treatments and of the clinical, milk, and blood disease phenotype recordings before and after intramammary $E$. coli inoculation at 0 $\mathrm{h}$ are presented in Table 1.

\section{Housing, Feeding, and Milking}

Prior to calving, the heifers were housed in a freestall barn. After calving, the cows were transferred to a straw-bedded tiestall barn. Eight days before the experimentally induced $E$. coli mastitis, the cows were moved so that they were kept with an empty tiestall between them during the remaining study period. One week before disease induction, the cows had a mean BW of $547 \pm 74 \mathrm{~kg}$ for the HL group versus $547 \pm$ $46 \mathrm{~kg}$ for the $\mathrm{HH}$ group. Moreover, a BCS of $3.0 \pm$ 0.3 versus $3.0 \pm 0.4$ was recorded for the $\mathrm{HL}$ and $\mathrm{HH}$ groups, respectively (Troels Kristensen's 1 to 5 scale; 
Table 1. Time points (hour and day) of the experimental treatments and disease phenotype recordings before and after intramammary Escherichia coli inoculation in dairy cows at $0 \mathrm{~h}$

\begin{tabular}{|c|c|c|}
\hline \multirow[b]{2}{*}{ Treatment and recording } & \multicolumn{2}{|l|}{ Time } \\
\hline & Hour & Day \\
\hline Liver biopsy & $-144,12,24,192$ & $-6,0.5,1,8$ \\
\hline Udder biopsy & 24,192 & 1,8 \\
\hline \multicolumn{3}{|l|}{ Clinical phenotypes } \\
\hline Feed intake & & -7 to 10 \\
\hline Heart rate & $0,3,6,12,18,24,36,60,84,132,180,228$ & 0 to 10 \\
\hline Respiration rate & $0,3,6,12,18,24,36,60,84,132,180,228$ & 0 to 10 \\
\hline Rumen motility & $0,3,6,12,18,36,60,84,132,180,228$ & 0 to 10 \\
\hline \multicolumn{3}{|l|}{ Paraclinical milk phenotypes } \\
\hline Bacterial counts & $\begin{array}{l}0,3,6,12,18,24,36,48,60,72,84,96,108,120,132,144,156,168,180,192, \\
204,216,228,240\end{array}$ & 0 to 10 \\
\hline
\end{tabular}

${ }^{1} \mathrm{MAA}=$ milk amyloid $\mathrm{A}$.

${ }^{2} \mathrm{WBC}=$ white blood cells

${ }^{3} \mathrm{SAA}=$ serum amyloid $\mathrm{A}$

Kristensen, 1986). A TMR diet based on corn silage plus minerals and vitamins was fed ad libitum twice per day in equal portions at about 0800 and $1530 \mathrm{~h}$. The diet and mineral supplementation were formulated to fulfill the nutrient requirements for dairy cows according to Danish standards. Feed intake was measured twice per day, and the cows were ensured free access to water. The cows were milked twice per day at 0600 and $1700 \mathrm{~h}$.

\section{Preparation of Bacteria and IMI}

The procedures for collection, preparation, and IMI of the bacteria were described by Buitenhuis et al. (2011). Danish field isolate E. coli strain (k2bh2) isolated from a cow with severe, acute mastitis was used in this experiment. Each cow was inoculated with $10 \mathrm{~mL}$ pyrogen-free $0.9 \%$ sodium chloride solution containing approximately 20 to $40 \mathrm{E}$. coli cfu after the evening milking (time $0 \mathrm{~h}$ ), following the inoculation procedure described in Vels et al. (2009). The front quarter with the lowest SCC $(<100,000$ cells $/ \mathrm{mL})$ was used for the E. coli inoculations.

\section{Collection of Liver and Udder Biopsies}

Four liver biopsies were taken as described by Vels et al. (2009) at -144, 12, 24, and 192 h PI; 2 udder biopsies were taken as described by Buitenhuis et al. (2011) at $24 \mathrm{~h}$ and $192 \mathrm{~h}$ PI. Liver biopsies were collected after local anesthesia with $10 \mathrm{~mL}$ of $2 \%$ lidocaine (Skander- borg Apotek, Skanderborg, Denmark). Udder biopsies were collected after the liver biopsies from cows sedated by i.v. administration of Domosedan vet. $(10 \mathrm{mg} / \mathrm{mL}$; detomidine; Orion Pharma, Espoo, Finland) at $0.1 \mathrm{~mL}$ per $100 \mathrm{~kg}$ of $\mathrm{BW}$ and were given local anesthesia on the udder skin using xylocaine (1\% lidocaine; Astra Zeneca A/S, Albertslund, Denmark). After udder biopsy, a prophylactic antibiotic treatment against infection with gram-positive bacteria was administered to all biopsy cows by i.m. injection of $30 \mathrm{~mL}$ of Penovet vet. (300,000 IU benzylpenicillin procaine/mL; Boehringer Ingelheim Danmark A/S, Copenhagen, Denmark).

\section{Additional Medical Treatment During the Disease Trial}

During the acute stage of mastitis, 1 cow (HHB), who responded severely to the $E$. coli mastitis was treated with Finadyne vet. (2.2 mg/kg, i.v.; Intervet/ScheringPlough, flunixin meglumine; $50 \mathrm{mg} / \mathrm{mL}$ ), Norodine vet. (16 mg/kg; ScanVet Animal Health A/S, Fredensborg, Denmark; containing sulfadiazine at $200 \mathrm{mg} / \mathrm{mL}$ and trimethoprim at $40 \mathrm{mg} / \mathrm{mL}$ ), Calciject 40 vet. (0.5 to $1 \mathrm{~mL} / \mathrm{kg}$; ScanVet Animal Health A/S; calcium borogluconate containing $30 \mathrm{mg}$ of $\mathrm{Ca} / \mathrm{mL}$ ), and $2 \mathrm{~L}$ of hypertonic sodium chloride solution [Vetivex 20; sodium chloride $7.2 \%$ (wt/vol); Jørgen Kruuse A/S] from 48 to $96 \mathrm{~h}$ PI. Another cow (HLB) developed a minor leg injury $72 \mathrm{~h}$ after $E$. coli challenge and was given antibiotic treatment for $3 \mathrm{~d}$ of 1 daily injection of Penovet vet. $(5 \mathrm{~mL} / 100 \mathrm{~kg}$, i.m.). No other cows were given 
medical treatment during the trial except for the treatment associated with the combined biopsies. Because of the relatively late medical treatment compared with the acute experimental disease stage, the 2 medically treated cows were retained in the statistical analysis.

\section{Blood and Milk Sampling}

Thirty-six hours before E. coli inoculation, sterile Micro-Renathane polyvinyl catheters (type S-54-HL; Norton Performance Plastics Co., Akron, $\mathrm{OH}$ ) were inserted into the jugular vein of each cow and flushed with a sterile $0.9 \%$ sodium chloride solution containing 50 to 200 IU of Na-heparin (Løvens Kemiske Fabrik, Ballerup, Denmark). Two sets of blood samples were drawn aseptically from the catheters with a syringe at the time points presented in Table 1. One set of blood samples was collected in 4-mL $\mathrm{K}_{3}$ EDTA blood tubes (Vacuette blood collection tubes; Greiner Bio-One, Hettich Labinstrument ApS, Hillerød, Denmark) and was analyzed for total and differential WBC count on a hemocytometer (Cell-Dyn 3500; Abbott Laboratories A/S, Copenhagen, Denmark). The other set was collected into 9-mL blood tubes stabilized with Na-heparin and immediately placed on ice for SAA analysis. The blood tubes were centrifuged at $2,000 \times g$ at $4^{\circ} \mathrm{C}$ for 20 min. Plasma was collected and stored at $-20^{\circ} \mathrm{C}$ until SAA analysis.

Milk samples were collected as foremilk samples before milking at the time points shown in Table 1. Sterile 10 -mL foremilk samples were collected for bacteriological investigations from the E. coli-inoculated quarter. In addition, the negative control quarter was sampled before udder biopsy at $24 \mathrm{~h}$ and $192 \mathrm{~h} \mathrm{PI}$, or if the CMT test indicated the presence of mastitis in quarters other than the inoculated quarter. Samples for SCC and MAA analysis were collected after the samples for bacteriological analysis. This milk was collected in 50$\mathrm{mL}$ sterile tubes and filtered through a $100-\mu \mathrm{m}$ filter to remove major pus aggregates before it was distributed into smaller tubes. Somatic cell count analysis was conducted immediately after sampling; all other samples were kept on ice and then frozen at $-20^{\circ} \mathrm{C}$.

\section{Recordings of Clinical Parameters}

The clinical response parameters included feed intake $(\mathrm{kg} / \mathrm{d})$, milk yield $(\mathrm{L} / \mathrm{d})$, body temperature $\left({ }^{\circ} \mathrm{C}\right)$, heart rate (beats/min), respiration rate (breaths/min), and rumen motility (contractions/3 min). Feed intake was calculated as the allowance in the morning and afternoon minus the total leftover. The daily feed intake and milk yield data were collected from the barn records twice per day. The udder condition (inflammation) in the E. coli-inoculated gland was scored as described in Rasmussen et al. (2011; data not shown). Together, the production parameters and clinical responses were defined as the clinical disease phenotypes.

\section{Recordings of Paraclinical Parameters}

The milk parameters, defined as the milk disease phenotype, included bacterial counts, SCC, and MAA concentration. In addition, the CMT test was used to screen foremilk samples from all 4 quarters to monitor the general udder health during the trial (data not shown).

Escherichia coli numbers (cfu/mL) were quantified as described in Buitenhuis et al. (2011). Furthermore, at several time points, $10-\mu \mathrm{L}$ aliquots of foremilk from the E. coli-infected quarter as well as the negative control quarter used for udder biopsy were cultured on blood agar and tryptic soy agar for $48 \mathrm{~h}$ at $37^{\circ} \mathrm{C}$ to test for the presence of mastitis pathogens other than E. coli. The SCC (cells $/ \mathrm{mL}$ ) of milk samples was measured in the barn using a portable DeLaval cell counter (DCC; DeLaval Holding AB, Tumba, Sweden; range 10 to $4,000 \times 10^{3}$ cells $/ \mathrm{mL}$ ).

Milk samples collected just before udder biopsy at 24 h contained coagulase-negative Staphylococcus spp. in the negative control quarter of 3 cows, with 2 cows showing elevated SCC from 500,000 cells/mL to 650,000 cells $/ \mathrm{mL}$. Otherwise, no mastitis pathogens other than E. coli were identified.

Milk amyloid A concentrations were measured using a commercially available ELISA kit (Tridelta Development Ltd., Bray Co., Wicklow, Ireland) according to the manufacturer's instructions. The milk samples were diluted 1:2,500 and tested in duplicate. Test samples outside the range of the standard curve were further diluted up to a maximum of 1:10,000. The interassay and intraassay coefficients of variation for the ELISA were $<12 \%$ of the positive control $(107.2 \mu \mathrm{g} / \mathrm{mL})$ at dilution $1: 50,000$ and $<20 \%$ of the positive control (428.5 $\mu \mathrm{g} / \mathrm{mL}$ ) at dilution $1: 50,000$. The detection limit of the ELISA was $0.1 \mu \mathrm{g} / \mathrm{mL}$.

The blood parameters, defined as blood disease phenotype, included WBC, PMNL, and SAA. White blood cell and leukocyte differential counts were calculated using a hemocytometer (Cell-Dyn 3500; Abbott Laboratories A/S). Only the WBC $\left(10^{6}\right.$ cells $\left./ \mathrm{mL}\right)$ and PMNL $\left(10^{6}\right.$ cells $\left./ \mathrm{mL}\right)$ data are reported in this study.

Plasma concentrations of SAA $(\mathrm{ng} / \mathrm{mL})$ were measured using a commercially available ELISA kit (Tridelta Development Ltd.) as described in Vels et al. (2009). The plasma samples were initially diluted 1:500 and tested in duplicate. Test samples outside the range of the standard curve were further diluted to a 
maximum of 1:2,000. The interassay and intraassay coefficients of variation for the ELISA were $<9.5 \%$ of the positive control $(16.1 \mu \mathrm{g} / \mathrm{mL})$ at dilution 1:500 and $<10 \%$ of the positive control $(155.1 \mu \mathrm{g} / \mathrm{mL})$ at dilution 1:2,000. The detection limits of the ELISA were 9.5 to $150 \mu \mathrm{g} / \mathrm{mL}$.

\section{Statistical Analysis}

The data were analyzed using the nlme (package 3.1-96) function in $\mathrm{R}$ (version 2.12.1, http://www.rproject.org/). The clinical, milk, and blood disease phenotypes were considered response variables to test the effect of the QTL haplotype. Phenotypic observations at different time points (Table 1) were analyzed using a linear mixed model. The following models (M) were used in the analyses:

$$
\begin{gathered}
\text { M1: } y_{i j k l}=t_{i}+q t l_{j}+b_{l}+t_{i} \times q t l_{j}+t_{i} \times b_{l} \\
+q t l_{j} \times b_{l}+t_{i} \times q t l_{j} \times b_{l}+a_{k}+e_{i j k l} ; \\
\mathrm{M} 2: y_{i j k l}=t_{i}+q t l_{j}+b_{l}+t_{i} \times q t l_{j} \\
\quad+t_{i} \times b_{l}+a_{k}+e_{i j k l} ; \\
\text { M3: } y_{i j k l}=t_{i}+q t l_{j}+b_{l}+t_{i} \times b_{l}+a_{k}+e_{i j k l} ; \\
\text { M4: } y_{i k l}=t_{i}+b_{l}+t_{i} \times b_{l}+a_{k}+e_{i k l} .
\end{gathered}
$$

In the above models, $y_{i j k l}$ was the response variable (disease phenotype), $t_{i}$ was the $i$ th time point measured in days for feed intake and milk yield and in hours for the other disease phenotypes, $q t l_{j}$ was the QTL haplotype effect of the $j$ th haplotype (HL or $\mathrm{HH}$ ), $b_{l}$ was the biopsy effect of the lth biopsy (B or NB), $a_{k}$ was the random effect of the $k$ th cow, and $e_{i j k l}$ was the random error associated with the measurement at the ith time point for the $j$ th haplotype, lth biopsy, and $k$ th cow. Measurements at different time points (Table 1) for the same animal were assumed to be correlated using a first-order autoregressive structure.

In the full model (M1), the main and interaction effects of the QTL haplotype and biopsy were assumed to be time dependent. Model 2 (M2) included the main effects of QTL haplotype and biopsy that were both time dependent. Model 3 (M3) included the main effect of QTL haplotype that was additive and the main effect of biopsy that was time dependent. Model 4 (M4) included the main effect of biopsy that was time dependent (this is the most reduced model). The models were compared using a likelihood ratio test. We tested M1 against M2 (test for time-dependent interaction effects between QTL haplotype and biopsy), M2 against M3 (test for time-dependent effect of QTL haplotype), and M3 against M4 (test for effect of QTL haplotype that is consistent over time).

All tests were considered significant if $P<0.05$. Because of large variations for the SCC, MAA, PMNL, and $E$. coli values in milk, these parameters were $\log _{2}$ transformed before statistical analysis.

\section{RESULTS}

Intramammary E. coli inoculation resulted in acute clinical E. coli mastitis in 29 of the 30 inoculated cows (statistical values not shown). After $72 \mathrm{~h}$, half of the cows (16 of 29) had cleared the E. coli infection. After $180 \mathrm{~h}$, all cows had cleared the infection, except for 3 cows that remained intermittently positive for $E$. coli during the remaining study period.

The QTL haplotype factor affected the paraclinical disease phenotypes SCC (consistent effect) and PMNL (time-dependent effect). Furthermore, the HH group tended to exhibit a higher clinical disease phenotype response (body temperature and heart rate) than the HL group. The biopsy factor showed statistically significant interactions with the QTL haplotype effects on body temperature, heart rate, and PMNL (Table 2).

\section{Effect of QTL Haplotype on Clinical Disease Phenotypes}

Escherichia coli mastitis lowered feed intake, milk yield and rumen motility, but increased body temperature, heart rate, and respiration rate in all infected cows (Figures 1 and 2).

Intramammary E. coli infection decreased feed intake by $47.2 \%$ for HL and $37.9 \%$ for $\mathrm{HH}$ (Figure 1A) and milk yield by $31.4 \%$ for HL and $35 \%$ for $\mathrm{HH}$ (Figure 1B). However, no significant differences were found between the HL and HH groups for feed intake and milk yield under either the interaction or the additive model (Table 2).

Quantitative trait locus haplotype had no consistent effect on body temperature, but the $\mathrm{HH}$ group tended to have higher body temperatures than the HL group $(P=0.07)$ during the acute disease stage (Table 2; Figure $2 \mathrm{~A})$. All 29 cows developed fever $\left(>39^{\circ} \mathrm{C}\right)$ within 12 to $18 \mathrm{~h}$ of infection, with mean peak temperatures of $40.2^{\circ} \mathrm{C}$ at $12 \mathrm{~h} \mathrm{PI}$ and $39.9^{\circ} \mathrm{C}$ at $18 \mathrm{~h} \mathrm{PI}$ in groups $\mathrm{HH}$ and HL, respectively. Mean body temperature remained above preinfection values $\left(38.5^{\circ} \mathrm{C}\right)$ until $18 \mathrm{~h}$ PI for the HL group, but remained elevated for an additional $6 \mathrm{~h}$ until $24 \mathrm{~h} \mathrm{PI}$ in the $\mathrm{HH}$ group.

The mean heart rate was relatively high during the whole trial ( $>70$ beats $/ \mathrm{min}$ ) and it followed the pattern of the body temperature. The heart rate was increased 
Table 2. Effect of Escherichia coli-associated QTL haplotype on the clinical, milk, and blood disease phenotypes of experimentally induced Escherichia coli mastitis in dairy cows

\begin{tabular}{|c|c|c|c|}
\hline Parameter $^{1}$ & $\begin{array}{c}P \text {-value }{ }^{2} \\
\left(\mathrm{M} 1^{3} \text { vs. M2 } 2^{4}\right)\end{array}$ & $\begin{array}{c}P \text {-value } \\
\left(\mathrm{M}^{4} \text { vs. } \mathrm{M} 3^{6}\right)\end{array}$ & $\begin{array}{c}P \text {-value } \\
\left(\mathrm{M}^{6}{ }^{6} \text { vs. } \mathrm{M} 4^{8}\right)\end{array}$ \\
\hline \multicolumn{4}{|l|}{ Clinical phenotype } \\
\hline Feed intake & 0.36 & 0.51 & 0.14 \\
\hline Milk yield & 0.94 & 0.97 & 0.70 \\
\hline Body temperature & $0.004^{* *}$ & $0.07 \dagger$ & 0.42 \\
\hline Heart rate & $0.01^{*}$ & $0.08 \dagger$ & 0.71 \\
\hline Respiration rate & 0.77 & 0.72 & 0.95 \\
\hline Rumen motility & 0.33 & 0.76 & 0.92 \\
\hline \multicolumn{4}{|c|}{ Paraclinical milk phenotype } \\
\hline Bacterial count & 0.82 & 0.99 & 0.58 \\
\hline SCC & 0.19 & 0.80 & $0.02^{*}$ \\
\hline MAA & 0.40 & 0.85 & 0.15 \\
\hline \multicolumn{4}{|c|}{ Paraclinical blood phenotype } \\
\hline WBC count & 0.30 & 0.27 & 0.88 \\
\hline PMNL & $0.03^{* *}$ & $0.02^{*}$ & 0.95 \\
\hline SAA & 0.36 & 0.84 & 0.77 \\
\hline \multicolumn{4}{|c|}{${ }^{1} \mathrm{MAA}=$ milk amyloid $\mathrm{A} ; \mathrm{WBC}=$ white blood cells; SAA $=$ serum amyloid $\mathrm{A}$} \\
\hline \multicolumn{4}{|c|}{${ }^{2}$ Likelihood ratio test for time-dependent interaction effects between QTL haplotype and biopsy. } \\
\hline \multicolumn{4}{|c|}{$\begin{array}{l}{ }^{3} \mathrm{M} 1 \text { = model } 1 \text {, in which the main and interaction effects of the QTL haplotype and biopsy are assumed to be } \\
\text { time dependent (full model). }\end{array}$} \\
\hline \multirow{2}{*}{\multicolumn{4}{|c|}{$\begin{array}{l}{ }^{4} \mathrm{M} 2=\text { model } 2, \text { which includes the main effects of QTL haplotype and biopsy that are both time dependent. } \\
{ }_{5}^{5} \text { Likelihood ratio test for time-dependent effect of QTL haplotype. }\end{array}$}} \\
\hline & & & \\
\hline \multicolumn{4}{|c|}{$\begin{array}{l}{ }^{6} \mathrm{M} 3=\text { model } 3 \text {, which includes the main effect of QTL haplotype that is additive and the main effect of biopsy } \\
\text { that is time dependent. }\end{array}$} \\
\hline \multicolumn{4}{|c|}{${ }^{7}$ Likelihood ratio test for effect of QTL haplotype that is consistent over time. } \\
\hline \multicolumn{4}{|c|}{$\begin{array}{l}{ }^{8} \mathrm{M} 4=\text { model } 4 \text {, which includes the main effect of biopsy that is time dependent. } \\
\dagger P<0.1 ;{ }^{*} P<0.05 ;{ }^{*} P<0.01\end{array}$} \\
\hline
\end{tabular}

in both groups, which attained peak levels at $12 \mathrm{~h}$ PI, with 105 and 102 beats/min in the HH and HL groups, respectively (Figure 2C). The HH group had a higher heart rate than the HL group between 36 and $132 \mathrm{~h}$ PI; this was close to being statistically significant under the interaction model $(P=0.08)$.

The respiration rate was also relatively high during the trial ( $>30$ breaths/min). Faster respiration rates were found in the HH group than in the HL group over time but this was not statistically significant. Mean respiration rates peaked at $12 \mathrm{~h}$ PI in the $\mathrm{HH}$ group $(40.2$ breaths/min) and at $18 \mathrm{~h} \mathrm{PI}$ in the HL group (38.6 breaths/min), and then again at $132 \mathrm{~h} \mathrm{PI} \mathrm{(42} \mathrm{and} 40.5$ breaths/min in the $\mathrm{HH}$ and HL groups, respectively; Figure 2E).

No significant differences were found between the 2 QTL haplotypes with regard to rumen motility (Figure $2 \mathrm{~F})$. The lowest mean values for rumen contractions were observed at $12 \mathrm{~h}$ PI, with the HL group having 2.7 contractions/ 3 min and the $\mathrm{HH}$ group having 3.1 contractions $/ 3 \mathrm{~min}$; both were significantly lower than the motility recorded before inoculation.

\section{Effect of QTL Haplotype on Paraclinical Disease Phenotypes}

Quantitative trait locus haplotype had no time-dependent or consistent effect on E. coli shedding (Table
2; Figure 3A). The kinetics of the E. coli shedding were almost similar in the 2 cow groups, with a sharp primary peak around $24 \mathrm{~h}$ PI. This was followed by a minor secondary peak at $48 \mathrm{~h} \mathrm{PI}$, but only in the $\mathrm{HH}$ group. Numerically, we did observe that the HH group had a higher $E$. coli bacterial count in the early acute phase from $6 \mathrm{~h}$ to $18 \mathrm{~h}$ PI than the HL group. However, $E$. coli levels in this time period were not statistically significantly different $(P=0.16)$. Escherichia coli levels also appeared numerically higher at the same time points in the HH group than the HL from $24 \mathrm{~h}$ PI to $48 \mathrm{~h}$ PI. In the recovery phase (60 to $240 \mathrm{~h} \mathrm{PI}$ ), $50 \%$ of cows in the HL group had 1 or more milk samples that were positive for $E$. coli at a given time point compared with $62 \%$ of cows in the $\mathrm{HH}$ group.

Somatic cell count was significantly affected by QTL haplotype, which had a consistent additive effect on the SCC level (Table 2; M3 vs. M4). The SCC of the 2 cow groups followed the same kinetics. Although it cannot be seen in Figure 3B, the SCC level already started to differ from $6 \mathrm{~h}$ PI, and tended to differ significantly between the 2 groups in the time period from 6 to 18 h PI $(P<0.10)$. Somatic cell counts peaked in both groups from $18 \mathrm{~h}$ to $24 \mathrm{~h} \mathrm{PI}$, where the upper limit of the DCC measuring capability was reached for most cows. After the SCC peak from approximately $36 \mathrm{~h} \mathrm{PI}$, the HH group continued to have a consistently higher 
A

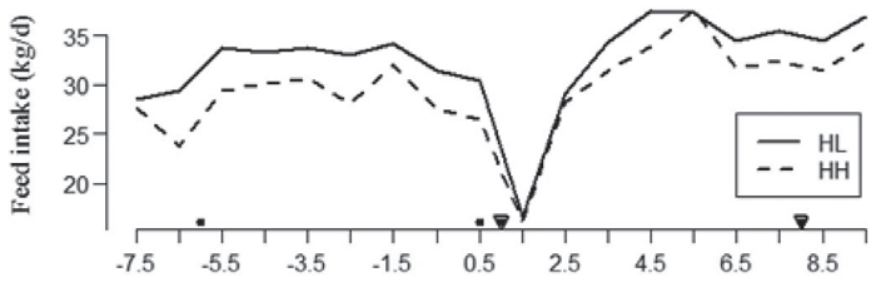

B

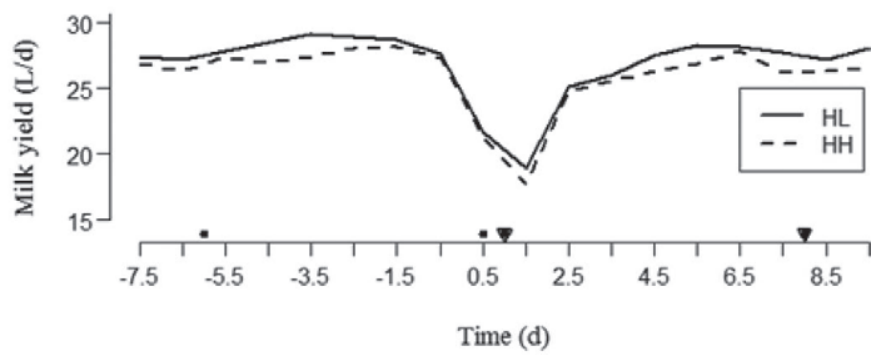

Figure 1. Effect of Bos taurus autosome 9 (BTA9) QTL haplotypes on clinical disease phenotypes related to production in 2 groups of dairy cows challenged with Escherichia coli mastitis. The results are reported as LSM and show the difference between each group by time. A: feed intake $(\mathrm{kg} / \mathrm{d})$; B: milk yield $(\mathrm{kg} / \mathrm{d})$. $\mathrm{HL}=$ low-susceptibility QTL haplotype; $\mathrm{HH}=$ high-susceptibility QTL haplotype. Liver biopsies $(\mathbf{\square})$ were collected at $-6,0.5,1$, and $8 \mathrm{~d}$ postinoculation (PI). Udder biopsies $(\mathbf{\nabla})$ were collected at 1 and $8 \mathrm{~d}$ PI. The SEM were 1.7 and 1.8 to 1.9 for feed intake, and 1.4 to 1.5 and 1.5 to 1.6 for milk yield, for the HL and $\mathrm{HH}$ groups, respectively. Quantitative trait loci haplotypes had no effect on feed intake or milk yield $(P>0.05)$.

SCC than the HL group did $(P<0.05)$. Hence, the HL group had a lower SCC at the end of the study period and a faster recovery, based on SCC.

Milk amyloid A levels were not affected by QTL haplotype group. The peak MAA levels in both the HL and $\mathrm{HH}$ groups occurred at approximately $60 \mathrm{~h}$ PI. At this time point we also observed the greatest numerical difference in MAA levels between the 2 groups (Figure 3C). The MAA level remained numerically higher in the HH group until approximately $132 \mathrm{~h} \mathrm{PI}$, after which time it returned to almost the same level in the 2 groups.

Although the WBC mean values differed between the $\mathrm{HL}$ and $\mathrm{HH}$ groups in the acute disease stage and the recovery stage (Figure 4A), WBC count was not significantly affected by QTL haplotype at any time point (Table 2). The WBC levels decreased to a minimum at $18 \mathrm{~h}$ PI (leukopenia), which was followed by an increasing trend (leukocytosis) that peaked at 36 and $60 \mathrm{~h} \mathrm{PI}$ in the HL and HH groups, respectively (Figure 4A).

The PMNL count mirrored the kinetics of the WBC count. Although no consistent effect was observed of haplotype on PMNL numbers, a time-dependent haplotype effect was found between HL and $\mathrm{HH}$ groups
(Table 2; M2 vs. M3). The PMNL count decreased to a minimum at 12 to $18 \mathrm{~h} \mathrm{PI}$, but was followed by a marked increase. The PMNL count peaked at 36 and 60 $\mathrm{h}$ PI in the HL and HH groups, respectively, with the HL group peaking more than $24 \mathrm{~h}$ before the $\mathrm{HH}$ group (Figure 4B). The peak PMNL level in the HL group was $5.7 \times 10^{6}$ cells $/ \mathrm{mL}$ and that in the $\mathrm{HH}$ group was $5.4 \times 10^{6}$ cells $/ \mathrm{mL}$.

The SAA blood concentrations started to increase after $E$. coli inoculation and reached peak levels from 24 to 60 h PI. Subsequently, SAA levels declined markedly and reached base levels at approximately $192 \mathrm{~h}$ PI in both groups (Figure 4D). The SAA level and kinetics were not significantly different between the 2 groups under either the interaction model or the additive model (Table 2).

\section{Interaction Between QTL Haplotype and Biopsy Effect}

The main effects of combined liver and udder biopsies on the clinical and paraclinical parameters of dairy cows with experimental E. coli mastitis will be published elsewhere (M. Khatun, unpublished data). The interaction effects of QTL haplotype group, biopsy, and sampling time are presented in Table 2 (M1 vs. M2). Interaction effects were found for body temperature, heart rate, and PMNL count. In the acute disease stage, biopsying increased body temperatures in both the HLB and HHB groups, and the HHB group exhibited higher temperatures than the HLB group did $(P<0.01$; Figure 2B). Heart rate followed the same pattern: the HHB group exhibited higher heart rates than the HLB group did $(P<0.05$; Figure 2D). After peaking at $36 \mathrm{~h}$ PI, PMNL count in the HLB group followed the kinetics of the HHB and HHNB groups, which remained significantly higher than that of the HLNB group throughout the study $(P<0.05$; Figure $4 \mathrm{C})$. No interaction effects were found between QTL haplotype group and biopsying for the other clinical and paraclinical parameters.

\section{DISCUSSION}

Genetic selection based on SCS is commonly used in breeding programs because of the high heritability of SCS and the availability of SCC data in well-organized field recording systems (Detilleux, 2009). Previous studies in dairy cows have demonstrated that SCS in Nordic HF cows is affected by QTL (Lund et al., 2008). Moreover, BTA9 QTL haplotype effects were demonstrated for pathogen-specific mastitis when investigating clinical mastitis recordings from the Danish cattle database (Sørensen et al., 2008). Likewise, QTL haplotypes 
A

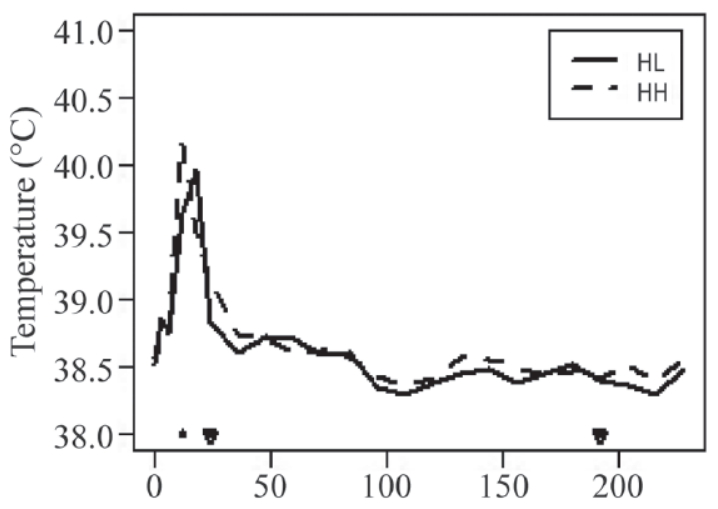

Time (h)

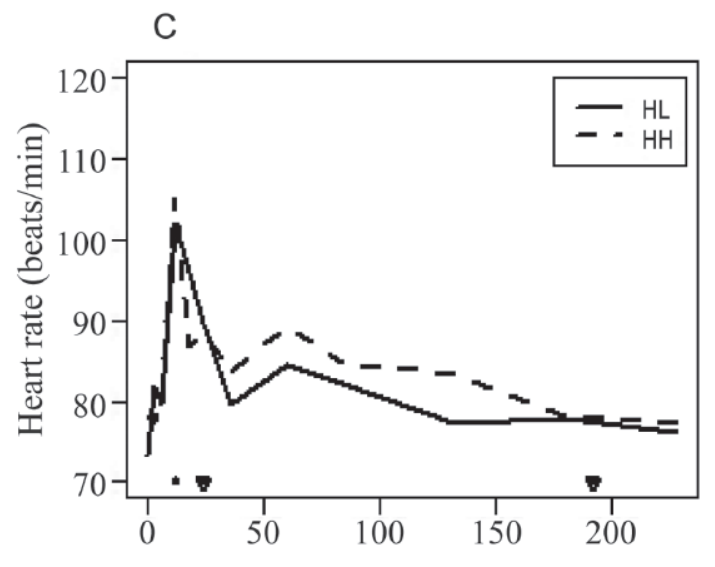

Time (h)

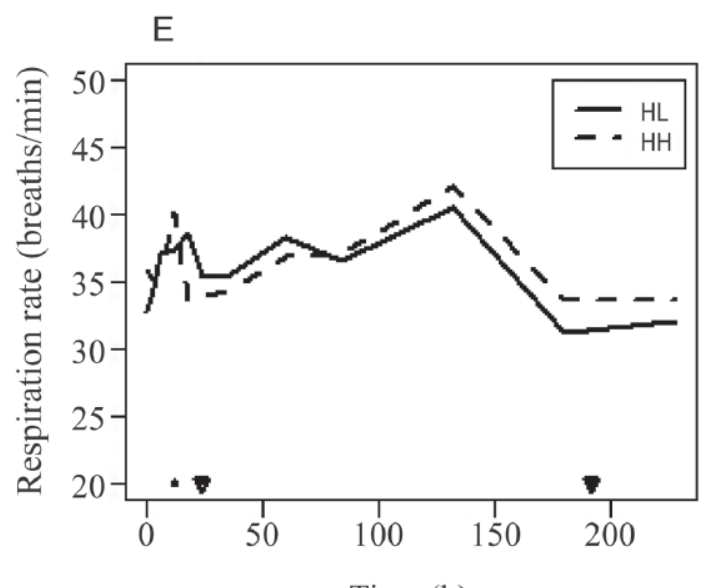

B

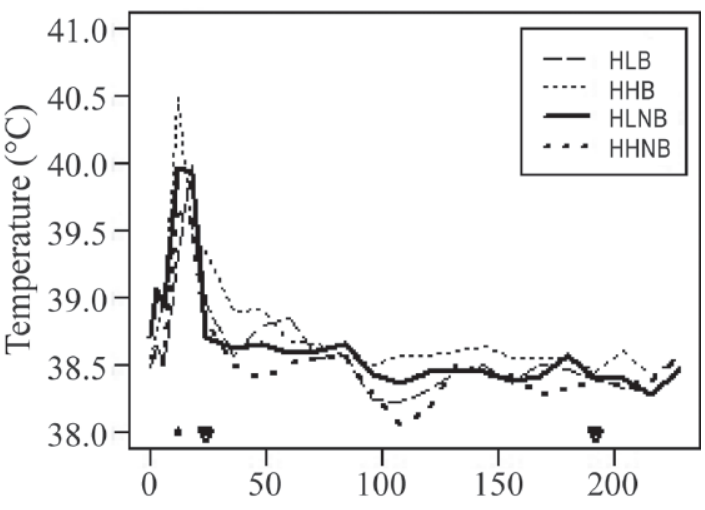

Time (h)

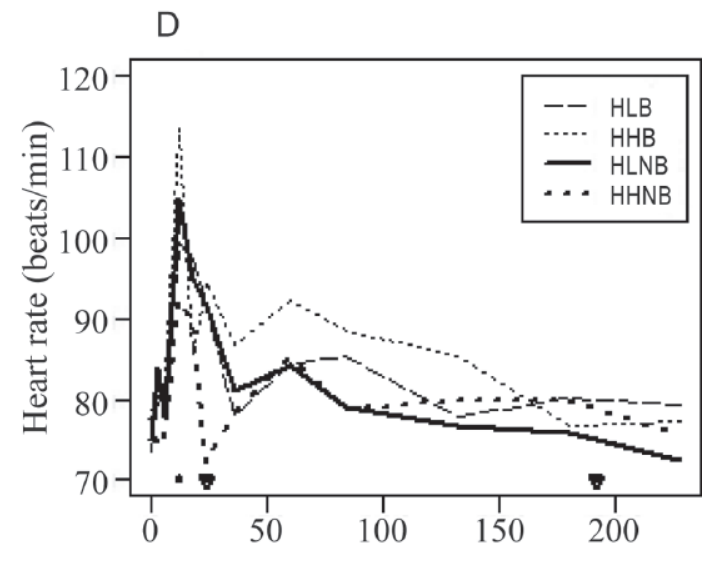

Time (h)

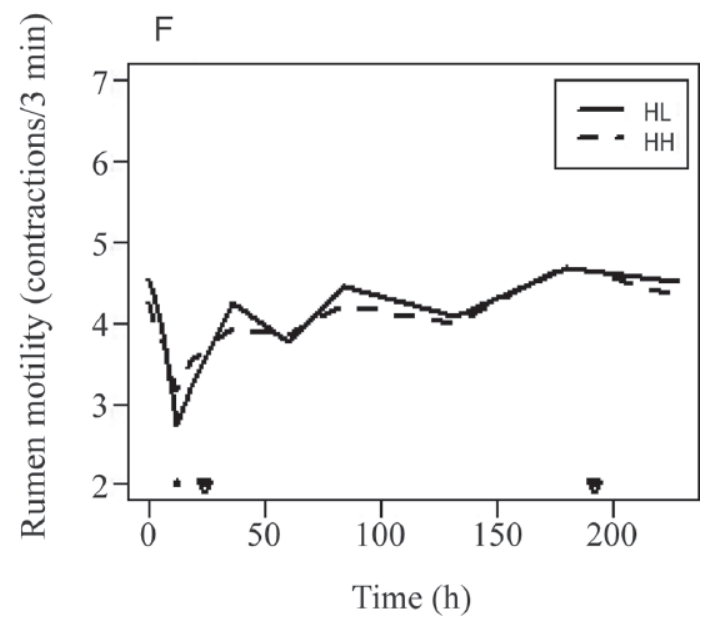

Figure 2. Effect of Bos taurus autosome 9 (BTA9) QTL haplotypes on clinical disease phenotypes in 2 groups of dairy cows challenged with Escherichia coli mastitis. The results are reported as LSM and show the difference between each group by time. A: body temperature response $\left({ }^{\circ} \mathrm{C}\right)$ due to haplotype effect; B: body temperature response $\left({ }^{\circ} \mathrm{C}\right)$ due to QTL haplotype and biopsy interaction effect; C: heart rate $($ beats/min) due to haplotype effect; D: heart rate (beats/min) due to haplotype and biopsy interaction effect; E: respiration rate (breaths/min); F: rumen motility (contractions $/ 3 \mathrm{~min}$ ). HL = low-susceptibility QTL haplotype; HH = high-susceptibility QTL haplotype; $\mathrm{B}=$ biopsied cows; NB $=$ nonbiopsied cows. Liver biopsies ( $\mathbf{\square})$ were collected at -144 (not shown), 24, and $192 \mathrm{~h}$ postinoculation (PI). Udder biopsies ( $\mathbf{\nabla})$ were collected at 24 and $192 \mathrm{~h} \mathrm{PI}$. The SEM for body temperature were 0.1 and 0.1; for heart rate, 2.6 to 4.9 and 2.9 to 5.6; for respiration rate, 2.5 to 4.1 and 2.8 to 4.1; and for rumen motility, 0.3 and 0.3 to 0.4 , for the HL and HH groups, respectively. A time-dependent effect of QTL haplotype was observed for body temperature and heart rate $(P<0.1)$. The 2 clinical disease phenotypes also varied due to a time-dependent interaction effect between QTL haplotype and biopsy $(P<0.05)$. 


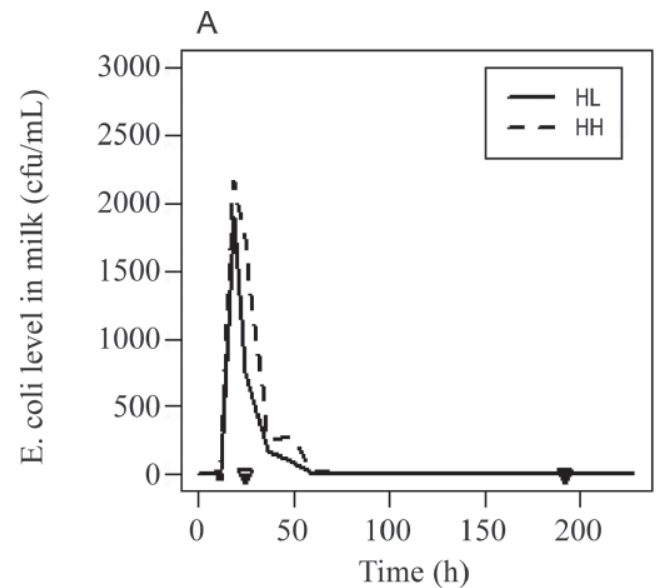

B
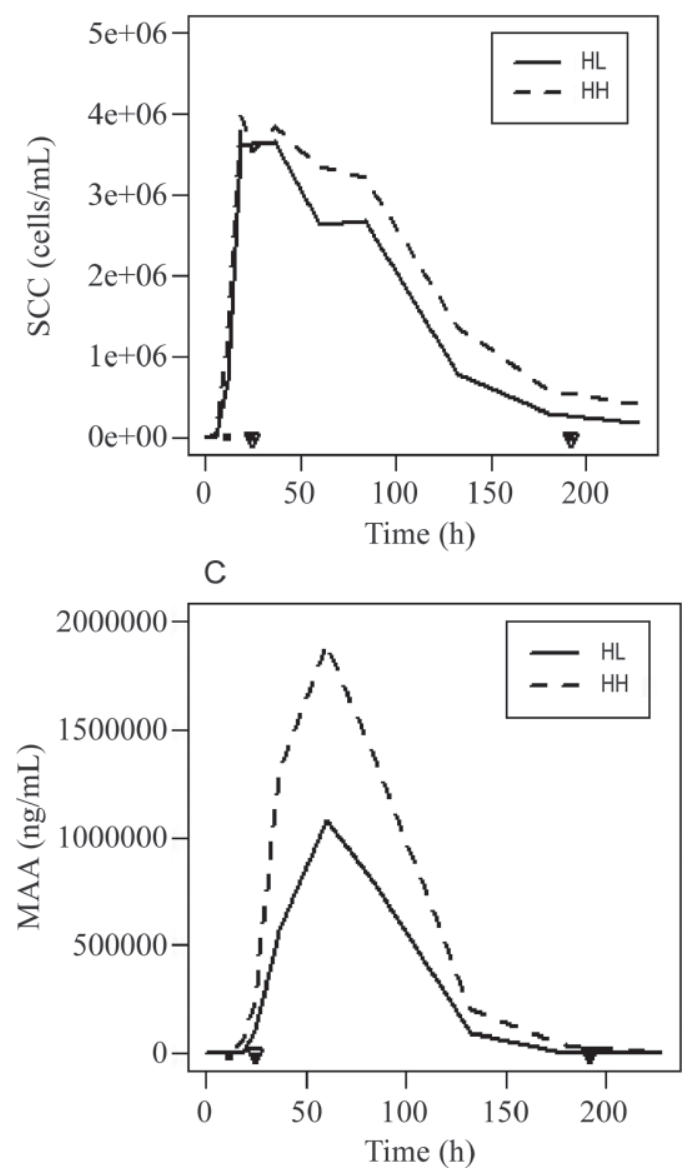

Figure 3. Effect of Bos taurus autosome 9 (BTA9) QTL haplotypes on paraclinical disease phenotypes related to milk in 2 groups of dairy cows challenged with Escherichia coli mastitis. The results are reported as LSM and show the difference between each group by time. A: E. coli level in milk (cfu/mL); B: SCC (cells $/ \mathrm{mL})$; C: milk amyloid A $($ MAA, ng $/ \mathrm{mL}) . \mathrm{HL}=$ low-susceptibility QTL haplotype; $\mathrm{HH}=$ high-susceptibility QTL haplotype. Liver biopsies (ם) were collected at -144 (not shown), 12, 24, and $192 \mathrm{~h}$ postinoculation (PI). Udder biopsies ( $\mathbf{\nabla})$ were collected at 24 and $192 \mathrm{~h}$ PI. The SEM were 0.6 to 0.7 and 0.7 to 0.8 for E. coli level, 0.3 and 0.3 for SCC level, and 0.6 and 0.7 for MAA level, for the HL and HH groups, respectively. Somatic cell counts differed consistently over time $(P<0.05)$. partly associated with $E$. coli mastitis were identified, with one QTL haplotype being more susceptible to this mammary gland infection and another QTL haplotype being more resistant to the infection (Sørensen et al., 2008). In the present study, we hypothesized that SCC and other clinical and paraclinical disease phenotypes of dairy cows associated with E. coli mastitis could be affected by these QTL haplotypes on BTA9. Hence, we established an experimental disease model in dairy cows to illustrate these QTL haplotype differences using SCC and other clinical and inflammatory parameters. Because high doses of $E$. coli would lead to serious mastitis (severe pathogen effect) regardless of haplotype and lower doses tend to result in large individual variations in disease response (Kornalijnslijper et al., 2004; Vangroenweghe et al., 2004), we chose a low-dose model (20 to $40 \mathrm{cfu} / \mathrm{mL}$ in 1 quarter). Escherichia coli infection was successfully established in 29 of 30 inoculated cows. The infected cows developed acute E. coli mastitis that ranged from mild to severe mastitis in both QTL haplotype groups and followed the disease kinetics and response described by others (Burvenich et al., 2003; Vangroenweghe et al., 2005)). Likewise, E. coli mastitis lowered feed intake, rumen motility, and milk yield, but increased body temperature, heart rate, and respiration rate and the concentrations of milk- and blood-related inflammatory mediators in the infected cows. In healthy cows exposed to experimental E. coli mastitis, the infection is brief in the majority of cows because of active pathogen clearance by the host (Bannerman et al., 2004; Kornalijnslijper et al., 2004; Suojala et al., 2008). Spontaneous recovery from E. coli mastitis will occur within 7 to $14 \mathrm{~d}$ without any medical treatment. This was also the case in our study. As was our intention, the low $E$. coli dose resulted in large individual variations with regard to $E$. coli number and shedding period. Major individual variations were found for both QTL haplotypes, and were highest in the HH group. Although we did observe a numerically higher E. coli count from 24 to 48 h PI, no statistical effect of QTL haplotype on E. coli levels could be documented in either the early and acute disease stage in which the $E$. coli levels peaked, or in the recovery period. Our finding is in contrast to that reported by Bonnefont et al. (2011), who demonstrated an effect on Staphylococcus aureus shedding in the dairy Lacaune sheep line bred for low and high SCC in second lactation, but in accordance with the same study, which was unable to document an effect on Staphylococcus epidermidis shedding in first lactation. Also, in their study, sheep were inoculated with $1,000 \mathrm{cfu} / \mathrm{mL}$ in 1 quarter. In our study, we only used primiparous cows for the E. coli mastitis challenge, which are known to have a lower clinical response and a faster recovery 

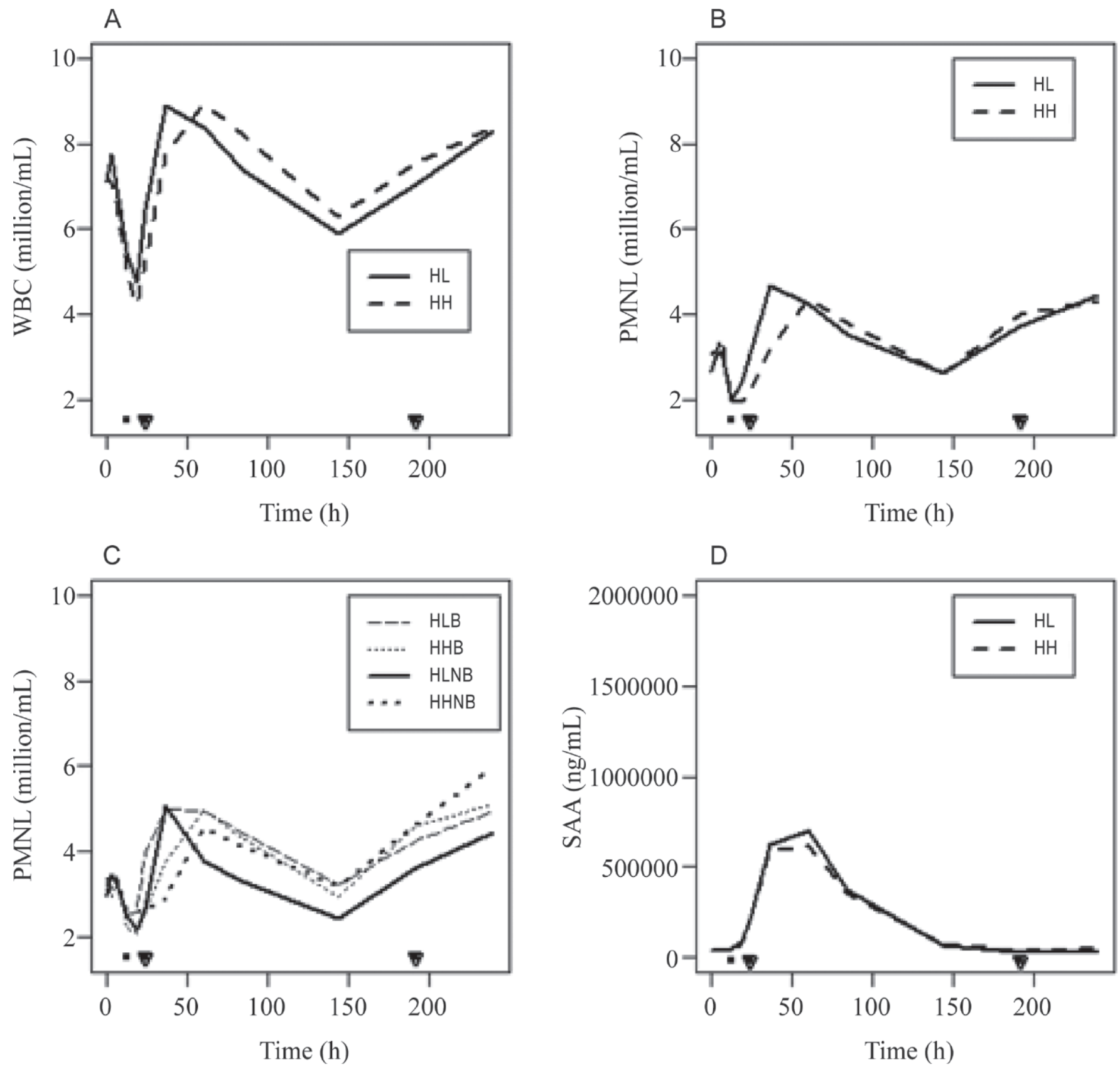

Figure 4. Effect of Bos taurus autosome 9 (BTA9) QTL haplotypes on paraclinical disease phenotypes related to blood in 2 groups of dairy cows challenged with Escherichia coli mastitis. The results are reported as LSM and show the difference between each group by time. A: white blood cell $(\mathrm{WBC})$ count $\left(10^{6}\right.$ cells $\left./ \mathrm{mL}\right)$; B: PMNL response $\left(10^{6}\right.$ cells $\left./ \mathrm{mL}\right)$; C: PMNL response due to haplotype and biopsy interaction effect $\left(10^{6}\right.$ cells $\left./ \mathrm{mL}\right)$; D: serum amyloid A level $(\mathrm{SAA} ; \mathrm{ng} / \mathrm{mL})$. HL = low-susceptibility QTL haplotype; HH = high-susceptibility QTL haplotype; $\mathrm{B}=$ biopsied cows; $\mathrm{NB}=$ nonbiopsied cows. Liver biopsies $(\mathbf{\square})$ were collected at -144 (not shown), 24, and $192 \mathrm{~h}$ postinoculation (PI). Udder biopsies $(\boldsymbol{\nabla})$ were collected at 24 and $192 \mathrm{~h} \mathrm{PI}$. The SEM were 0.6 and 0.6 for WBC count, 0.1 and 0.1 for PMNL level, and 31.9 to 33 and 35.1 to 36.6 for SAA level, for the HL and HH groups, respectively. A time-dependent effect of QTL haplotypes was observed for PMNL level $(P<$ 0.05). The PMNL level also varied due to a time-dependent interaction effect between QTL haplotype and biopsy $(P<0.05)$.

from E. coli mastitis than multiparous cows (Burvenich et al., 2003). Whether the use of multiparous cows or a different E. coli dose would have influenced the results remains to be investigated. Nevertheless, we were able to demonstrate that the QTL haplotype affected other paraclinical disease phenotypes induced by the intramammary E. coli infection, including SCC and PMNL.

Whereas Bonnefont et al. (2011) were unable to document an effect on SCS between the resistant and susceptible sheep lines, either before or after the chal- 
lenge with the 2 Staphylococcus species, we succeeded in demonstrating a BTA9 QTL haplotype effect on SCC level in HF cows after $E$. coli challenge. Indeed, the IMI with Staphylococcus spp. and our E. coli strain resulted in increased SCC and bacteria counts in both ruminant species. However, compared with Bonnefont et al. (2011), who sampled their sheep 3 to 4 times within a 48-h period postinoculation, we sampled the dairy cows 11 times for a period of $228 \mathrm{~h}$ postinoculation. Still, as E. coli is a gram-negative bacterium and Staphylococcus spp. are gram-positive bacteria, major differences are found in their disease pathogenesis and immune response when cows are infected (Bannerman et al., 2004; Schukken et al., 2011). Therefore, one should be careful comparing the 2 infection models with regard to SCC and leukocyte recruitment to the mammary gland.

Although the SCC levels in our study followed the same kinetics in the 2 cow groups, the SCC already started to differ in the early acute phase (from around $6 \mathrm{~h}$ ) before the SCC peak. Somatic cell count levels also differed in the late inflammatory phase and in the recovery period, where the level remained consistently higher in the HH group than in the HL group. Correspondingly, we observed a shorter SCC recovery $(<150,000$ cells $/ \mathrm{mL})$ period in the HL group compared with the HH group. However, no differences were found between the 2 groups for the SCC peak level within the 2 phases (from 18 to $24 \mathrm{~h}$ ). One possible explanation could be the method used to analyze the SCC. We used the handy DCC for bulk milk and cow-side testing (Røntved et al., 2005). This instrument is optimized to count somatic cells in the range 10,000 to $4,000,000$ cells/mL. However, it plateaus at 5,000,000 cells/ $\mathrm{mL}$, which results in high-cell-count samples yielding a similar SCC and a comparatively lower SCC than they would have by the Coulter count method or the Fossomatic cell counter (Foss Electric A/S, Hillerød, Denmark; Røntved et al., 2005). Indeed, this SCC level was reached for the majority of our milk samples from 18 to $24 \mathrm{~h}$.

The finding of a significant difference in SCC level between the 2 QTL haplotype groups provides further evidence of genetic influence on SCC and confirms previous findings for BTA9 (Lund et al., 2008; Sørensen et al., 2008). Clearly, E. coli number and SCC kinetics are associated with each other, as the colonization and multiplication of $E$. coli induces secretion of inflammatory mediators and tissue damage that mobilize leukocytes, especially PMNL to the infection site. Hence, genes related to SCC level and recruitment in the acute stage are expected to play a role in the pathogenesis. In contrast, the comparatively higher SCC in the $\mathrm{HH}$ group in the recovery stage may be associated with genes responsible for a higher inflammatory host response during the acute stage or a weakened ability to heal, or both.

In an older study, healthy dairy cows in early lactation were shown to have a high heritability of blood PMNL numbers (Detilleux et al., 1994). In this study, similar numbers of PMNL were found in blood in the 2 QTL haplotype groups both before and during E. coli mastitis (although influenced by biopsy), whereas milk PMNL numbers were not investigated. Hence, these 2 PMNL phenomena (numbers and kinetics) seem to be independent of each other.

Because of blood-derived leukocyte migration toward the udder during mastitis, WBC count will be decreased, resulting in short-term leukopenia in the acute disease stage, followed by leukocytosis in the recovery stage. In our E. coli study, both the WBC and PMNL counts followed this pattern during mastitis, which suggests that, in both QTL haplotype groups, these leukocytes were later replaced by newly produced leukocytes from the bone marrow. Interestingly, we observed a much faster recruitment of PMNL (24 h) in the HL group than in the $\mathrm{HH}$ group. Whether this PMNL recruitment is associated with the faster recovery in HL cows in terms of a lower SCC remains to be documented. Indeed, a faster recovery could be associated with less tissue trauma caused by lower numbers of PMNL that migrate though the secretory tissue into the milk, and lower concentrations of inflammatory mediators [for instance, tumor necrosis factor $\alpha(\mathbf{T N F}-\boldsymbol{\alpha})$ and proteolytic enzymes released from activated or dead PMNL].

The effects of QTL haplotype on the 2 cow groups' disease phenotype responses were also observed for 2 clinical parameters, as the $\mathrm{HH}$ group tended to exhibit a higher body temperature and heart rate than the $\mathrm{HL}$ group. Hence, the paraclinical parameters SCC and PMNL supported the clinical observation of a milder clinical response in the HL group. Fever, heart rate, and leukocyte mobilization are induced by proinflammatory mediators such as TNF- $\alpha$, IL-1, and IL-6 released during the acute-phase response (Vels et al., 2009). Hence, these mediators could be interesting to investigate in a future study. In relation to the acute-phase response in this study, we measured the acute-phase proteins SAA and MAA. Milk amyloid A, also known as SAA isotype 3 , is primarily produced in the udder during mastitis (Jacobsen et al., 2005; Molenaar et al., 2009). Serum amyloid A and MAA concentrations are associated with the degree of tissue damage in response to bacterial infection (Cray et al., 2009; Molenaar et al., 2009), where MAA can be further enhanced by udder biopsying (M. Khatun, P. Sørensen, K. L. Ingvartsen, M. Bjerring, and C. M. Røntved, unpublished data). In our study, large variation existed among individual 
cows with respect to both SAA and MAA concentrations in blood and milk, respectively. In accordance with our $E$. coli findings we were not able to document a QTL haplotype effect on E. coli-induced tissue damage in the mammary gland.

In addition to the factor QTL haplotype, we also investigated the factor biopsy. Biopsy did affect the clinical and paraclinical disease response transiently, including milk yield, E. coli shedding, and MAA concentration (M. Khatun, unpublished data). Further, we showed that a biopsy interaction with the QTL haplotype affected body temperature, heart rate, and PMNL, where the effect of QTL haplotype on these disease phenotypes was further increased by liver and udder biopsies in the $\mathrm{HH}$ group.

The immune response directed against E. coli in the bovine mammary gland primarily involves factors belonging to the innate immune system (Schukken et al., 2011). Recently, we have shown that genes and pathways associated with PMNL migration, such as pathogen-associated molecular pattern (PAMP) receptors, inflammatory cytokines, chemokines, chemokine receptors, and adhesion molecules, are significantly upregulated in the mammary gland during acute $E$. coli mastitis (Buitenhuis et al., 2011). Further, combining the transcriptome with the phenome and genome, we presented a list of 10 ranked genes likely to be related to mastitis susceptibility for the QTL (Jiang et al. 2012). The list includes factors directly or indirectly associated with PMNL recruitment, such as interferon $\gamma$ receptor 1 , vanin 1 , vanin 2 , IL-22 receptor $\alpha 2$, IL-20 receptor $\alpha$, and TNF $\alpha$-induced protein 3 .

Presently, we are investigating PMNL-related immunological factors and pathways, with altered expression profiles during $E$. coli mastitis that could be linked to the E. coli-associated QTL haplotypes. In Danish HF dairy cows, these BTA-9-associated factors are potential genetic targets for future selection of individuals with a milder clinical responsiveness and faster SCC recovery to $E$. coli mastitis.

\section{CONCLUSIONS}

Using an experimental E. coli mastitis model, we confirmed that QTL haplotypes on BTA9 in Danish HF cows are associated with SCC level during and after E. coli mastitis. Cows with the low-susceptibility QTL haplotype had a significantly faster SCC recovery and PMNL recruitment to the circulatory system than the high-susceptibility-QTL-haplotype cows did. Moreover, the low-susceptibility-QTL-haplotype cows tended to show milder a clinical response than the high-susceptibility-QTL-haplotype cows did; the latter group also had an augmented clinical response to $E$. coli mastitis in the presence of the additional stress of repeated liver and udder biopsying. Knowledge of QTL haplotype effects on clinical and paraclinical mastitis phenotypes provides avenues to gain insight into the genetic influences on E. coli mastitis.

\section{ACKNOWLEDGMENTS}

This study was partly funded by the European Union "Sustainable Animal Breeding" (SABRE) program, Work Package (WP) 5, Mammary gland function, and by the BIOSENS project granted by the Danish Ministry of Food, Agriculture, and Fisheries (Copenhagen V, Denmark; Innovations Law), Lattec I/S (Hillerød, Denmark), the Knowledge Centre for Agriculture, Cattle (Aarhus N, Denmark), and the Faculty of Agricultural Sciences, Aarhus University (Tjele, Denmark). Aarhus University granted the first author tuition-free enrollment and scholarship; this is given to Masters students from developing countries. We thank Helle Daugaard Larsen, formerly of the Danish Institute for Food and Veterinary Research (Copenhagen, Denmark), for the $E$. coli strain. Furthermore, we thank the laboratory technicians and barn staff of Aarhus University for their excellent technical assistance: Jens Clausen, Dorte Agnholt, Hanne Møller Purup, Elisabeth Mark, Lene Niklassen, Inger Marie Jepsen, Susanne Sommer, Pia Jensen, Jan Pedersen, Thomas Bitsch, Tina Hald, Ole Frank, and Erik Moestrup.

\section{REFERENCES}

Bannerman, D. D., M. J. Paape, J.-W. Lee, X. Zhao, J. C. Hope, and P. Rainard. 2004. Escherichia coli and Staphylococcus aureus elicit differential innate immune responses following intramammary infection. Clin. Diagn. Lab. Immunol. 11:463-472.

Bar, D., L. W. Tauer, G. Bennett, R. N. González, J. A. Hertl, Y. H Schukken, H. F. Schulte, F. L. Welcome, and Y. T. Gröhn. 2008. The cost of generic clinical mastitis in dairy cows as estimated by using dynamic programming. J. Dairy Sci. 91:2205-2214.

Bonnefont, C. M. D., M. Toufeer, C. Caubet, E. Foulon, C. Tasca, M.-R. Aurel, D. Bergonier, S. Boullier, C. Robert-Granié, G. Foucras, and R. Rupp. 2011. Transcriptomic analysis of milk somatic cells in mastitis resistant and susceptible sheep upon challenge with Staphylococcus epidermidis and Staphylococcus aureus. BMC Genomics 12:208.

Bradley, A. J., K. A. Leach, J. E. Breen, L. E. Green, and M. J. Green. 2007. Survey of the incidence and aetiology of mastitis on dairy farms in England and Wales. Vet. Rec. 160:253-257.

Brand, B., A. Hartmann, D. Repsilber, B. Griesbeck-Zilch, O. Wellnitz, C. Kühn, S. Ponsuksili, H. H. Meyer, and M. Schwerin. 2011. Comparative expression profiling of E. coli and S. aureus inoculated primary mammary gland cells sampled from cows with different genetic predispositions for somatic cell score. Genet. Sel. Evol. 43:24.

Buitenhuis, B., C. M. Røntved, S. M. Edwards, K. L. Ingvartsen, and P. Sørensen. 2011. In depth analysis of genes and pathways of the mammary gland involved in the pathogenesis of bovine Escherichia coli-mastitis. BMC Genomics 12:130.

Burvenich, C., D. D. Bannerman, J. D. Lippolis, L. Peelman, B. J. Nonnecke, M. E. Kehrli Jr., and M. J. Paape. 2007. Cumulative 
physiological events influence the inflammatory response of the bovine udder to Escherichia coli infections during the transition period. J. Dairy Sci. 90(E. Suppl. 1):E39-E54.

Burvenich, C., V. Van Merris, J. Mehrzad, A. Diez-Fraile, and L. Duchateau. 2003. Severity of E. coli mastitis is mainly determined by cow factors. Vet. Res. 34:521-564.

Cray, C., J. Zaias, and N. H. Altman. 2009. Acute phase response in animals: A review. Comp. Med. 59:517-526.

Detilleux, J. C. 2009. Genetic factors affecting susceptibility to udder pathogens. Vet. Microbiol. 134:157-164.

Detilleux, J. C., K. J. Koehler, A. E. Freeman, J. Kehrli, and D. H. Kelley. 1994. Immunological parameters of periparturient Holstein cattle: Genetic variation. J. Dairy Sci. 77:2640-2650.

Ericsson Unnerstad, H., A. Lindberg, K. Persson Waller, T. Ekman, K. Artursson, M. Nilsson-Öst, and B. Bengtsson. 2009. Microbial aetiology of acute clinical mastitis and agent-specific risk factors. Vet. Microbiol. 137:90-97.

Fogsgaard, K. K., C. M. Røntved, P. Sørensen, and M. S. Herskin. 2012. Sickness behavior in dairy cows during Escherichia coli mastitis. J. Dairy Sci. 95:630-638.

Fox, L. K. 2009. Prevalence, incidence and risk factors of heifer mastitis. Vet. Microbiol. 134:82-88.

Griesbeck-Zilch, B., M. Osman, Ch. Kühn, M. Schwerin, R. H. Bruckmaier, M. W. Pfaffl, A. Hammerle-Fickinger, H. H. Meyer, and O. Wellnitz. 2009. Analysis of key molecules of the innate immune system in mammary epithelial cells isolated from marker-assisted and conventionally selected cattle. J. Dairy Sci. 92:4621-4633.

He, Y., Q. Chu, P. Ma, Y. Wang, Q. Zhang, D. Sun, Y. Zhang, Y. Yu, and Y. Zhang. 2011. Association of bovine CD4 and STAT5b single nucleotide polymorphisms with somatic cell scores and milk production traits in Chinese Holsteins. J. Dairy Res. 78:242-249.

Hertl, J. A., Y. H. Schukken, D. Bar, G. J. Bennett, R. N. González, B. J. Rauch, F. L. Welcome, L. W. Tauer, and Y. T. Gröhn. 2011. The effect of recurrent episodes of clinical mastitis caused by gram-positive and gram-negative bacteria and other organisms on mortality and culling in Holstein dairy cows. J. Dairy Sci. 94:4863-4877.

Jacobsen, S., T. A. Niewold, E. Kornalijnslijper, M. J. M. Toussaint, and E. Gruys. 2005. Kinetics of local and systemic isoforms of serum amyloid A in bovine mastitic milk. Vet. Immunol. Immunopathol. 104:21-31.

Jiang, L., P. Sørensen, B. Thomsen, S. M. Edwards, A. Skarman, C. M. Røntved, M. S. Lund, and C. T. Workman. 2012. Gene prioritization for livestock diseases by data integration. Physiol. Genomics 44:305-317.

Jørgensen, H. B., B. Buitenhuis, C. M. Røntved, L. Jiang, K. L. Ingvartsen, and P. Sørensen. 2012. Transcriptional profiling of the bovine hepatic response to experimentally induced $E$. coli mastitis. Physiol. Genomics 44:595-606.

Kornalijnslijper, J. E., A. J. J. M. Daemen, T. van Werven, T. A. Niewold, V. P. M. G. Rutten, and E. N. Noordhuizen-Stassen. 2004. Bacterial growth during the early phase of infection determines the severity of experimental Escherichia coli mastitis in dairy cows. Vet. Microbiol. 101:177-186.

Kristensen, T. 1986. Method for estimation of body condition in dairy cows. Page 59-76 in Rep. No. DK8621430. Statens Husdyrbrugsfors $\varnothing \mathrm{g}$, Copenhagen, Denmark.

Leyva-Baca, I., F. Schenkel, J. Martin, and N. A. Karrow. 2008. Polymorphisms in the $5^{\prime}$ upstream region of the CXCR 1 chemokine receptor gene, and their association with somatic cell score in Holstein cattle in Canada. J. Dairy Sci. 91:407-417.

Lund, M. S., B. Guldbrandtsen, A. J. Buitenhuis, B. Thomsen, and C. Bendixen. 2008. Detection of quantitative trait loci in Danish Holstein cattle affecting clinical mastitis, somatic cell score, udder conformation traits, and assessment of associated effects on milk yield. J. Dairy Sci. 91:4028-4036.

Lund, M. S., P. Sørensen, B. Guldbrandtsen, and D. A. Sørensen. 2003. Multitrait fine mapping of quantitative trait loci using combined linkage disequilibria and linkage analysis. Genetics 163:405-410.
Molenaar, A. J., D. P. Harris, G. H. Rajan, M. L. Pearson, M. R. Callaghan, L. Sommer, V. C. Farr, K. E. Oden, M. C. Miles, R. S. Petrova, L. L. Good, K. Singh, R. D. McLaren, C. G. Prosser, K. S. Kim, R. J. Wieliczko, M. H. Dines, K. M. Johannessen, M. R. Grigor, S. R. Davis, and K. Stelwagen. 2009. The acute-phase protein serum amyloid A3 is expressed in the bovine mammary gland and plays a role in host defence. Biomarkers 14:26-37.

Petrovski, K. R., M. Trajcev, and G. Buneski. 2006. A review of the factors affecting the costs of bovine mastitis. J. S. Afr. Vet. Assoc. $77: 52-60$.

Pighetti, G. M., and A. A. Elliott. 2011. Gene polymorphisms: The keys for marker assisted selection and unraveling core regulatory pathways for mastitis resistance. J. Mammary Gland Biol. Neoplasia 16:421-432.

Pyörälä, S. 2003. Indicators of inflammation in the diagnosis of mastitis. Vet. Res. 34:565-578.

Rasmussen, D. B., K. Fogsgaard, C. M. Røntved, I. C. Klaas, and M. S. Herskin. 2011. Changes in thermal nociceptive responses in dairy cows following experimentally induced Escherichia coli mastitis. Acta Vet. Scand. 53:32.

Røntved, C. M., L. Nielsen, M. Bjerring, M. D. Rasmussen, O. Lind, and K. L. Ingvartsen. 2005. Somatic cell count analyses of milk performed with DeLaval Cell Counter DCC. Proc. 4th IDF Intl. Mastitis Conf.: Mastitis in Dairy Production: Current Knowledge and Future Solutions, Maastricht, the Netherlands. CD-ROM s. 874-887. Wageningen Academic Publishers, Wageningen, the Netherlands.

Sahana, G., M. S. Lund, L. Andersson-Eklund, N. Hastings, A. Fernandez, T. Iso-Touru, B. Thomsen, S. Viitala, P. Sorensen, J. L. Williams, and J. Vilkki. 2008. Fine-mapping QTL for mastitis resistance on BTA9 in three Nordic red cattle breeds. Anim. Genet. 39:354-362.

Schukken, Y. H., J. Günther, J. Fitzpatrick, M. C. Fontaine, L. Goetze, O. Holst, J. Leigh, W. Petzl, H.-J. Schuberth, A. Sipka, D. G. E. Smith, R. Quesnell, J. Watts, R. Yancey, H. Zerbe, A. Gurjar, R. N. Zadoks, and H.-M. Seyfert., and members of the Pfizer mastitis research consortium. 2011. Host- response patterns of intramammary infections in dairy cows. Vet. Immunol. Immunopathol. 144:270-289.

Sodeland, M., M. P. Kent, H. G. Olsen, M. A. Opsal, M. Svendsen, E. Sehested, B. J. Hayes, and S. Lien. 2011. Quantitative trait loci for clinical mastitis on chromosomes 2, 6, 14 and 20 in Norwegian Red cattle. Anim. Genet. 42:457-465.

Sørensen, L. P., B. Guldbrandtsen, J. R. Thomasen, and M. S. Lund. 2008. Pathogen-specific effects of quantitative trait loci affecting clinical mastitis and somatic cell count in Danish Holstein cattle. J. Dairy Sci. 91:2493-2500.

Stephens, M., and P. Donnelly. 2003. A comparison of Bayesian methods for haplotype reconstruction from population genotype data. Am. J. Hum. Genet. 73:1162-1169.

Suojala, L., T. Orro, H. Järvinen, J. Saatsi, and S. Pyörälä. 2008. Acute phase response in two consecutive experimentally induced E. coli intramammary infections in dairy cows. Acta Vet. Scand. $50: 18$

Vangroenweghe, F., L. Duchateau, P. Boutet, P. Lekeux, P. Rainard, M. J. Paape, and C. Burvenich. 2005. Effect of carprofen treatment following experimentally induced Escherichia coli mastitis in primiparous cows. J. Dairy Sci. 88:2361-2376.

Vangroenweghe, F., P. Rainard, M. Paape, L. Duchateau, and C. Burvenich. 2004. Increase of Escherichia coli inoculum doses induces faster innate immune response in primiparous cows. J. Dairy Sci. 87:4132-4144.

Vels, L., C. M. Røntved, M. Bjerring, and K. L. Ingvartsen. 2009. Cytokine and acute phase protein gene expression in repeated liver biopsies of dairy cows with a lipopolysaccharide-induced mastitis. J. Dairy Sci. 92:922-934. 